\title{
Inorganic Fertilizer Adoption, Use Intensity and Rainfed Rice Yield in Benin
}

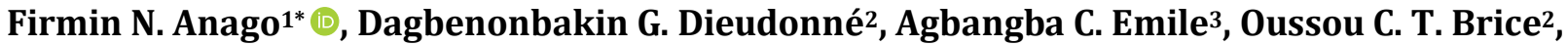 \\ Amadji L. Guillaume ${ }^{1}$ \\ ${ }^{1}$ Laboratory of Soil Sciences, School of Plant Production, Faculty of Agricultural Sciences, University of Abomey-Calavi, \\ Cotonou, Benin \\ ${ }^{2}$ Laboratory of Soil Science, Water and Environment, Research Agricultural Center of Agonkanmey, National Institute of \\ Agronomic Research of Benin, Cotonou, Benin \\ ${ }^{3}$ Laboratory of Applied Biology Research and Study, Polytechnic School of Abomey-Calavi, Department of Environment Genius, \\ University of Abomey-Calavi, Cotonou, Benin \\ Email: ^firmin.anago@gmail.com
}

How to cite this paper: Anago, F.N., Dieudonné, D.G., Emile, A.C., Brice, O.C.T. and Guillaume, A.L. (2020) Inorganic Fertilizer Adoption, Use Intensity and Rainfed Rice Yield in Benin. Open Journal of Soil Science, 10, 1-15.

https://doi.org/10.4236/ojss.2020.101001

Received: December 24, 2019

Accepted: January 17, 2020

Published: January 20, 2020

Copyright $\odot 2020$ by author(s) and Scientific Research Publishing Inc. This work is licensed under the Creative Commons Attribution International License (CC BY 4.0).

http://creativecommons.org/licenses/by/4.0/

(c) (i) Open Access

\begin{abstract}
Inorganic fertilizers are alternative ways of providing the necessary nutrients to rice crop and increase its productivity. In order to identify the factors determining inorganic fertilizer technology adoption and rainfed rice yield, a survey was carried out among 763 farmers in 11 municipalities in four agriculture development centers (ADC) of Benin. Composite soil samples were collected from 227 farmer fields and analyzed at the laboratory. Rainfed rice yields were determined in these different fields. Data collected was analyzed with $\mathrm{R}$ version 3.5.1 software. Results show that inorganic fertilizer technology adoption depends significantly on age, educational status, household size, contribution of rice to household income and organic fertilizer use $(0.004<\mathrm{p}<0.034)$. However, using intensity of inorganic fertilizer is significantly influenced by the age of the farmer, the quality of the training of the farmer on soil fertility management, filed areas under rice crop, contribution of rice to household income, years of farming experience, inorganic fertilizers availability and organic fertilizer use $(0.0001<\mathrm{p}<0.023)$. Inorganic fertilizer use intensity ranges from 12.6 to $248.9 \mathrm{~kg} \cdot \mathrm{ha}^{-1}$ with a mean of 74.68 $\mathrm{kg} \cdot \mathrm{ha}^{-1}$. The quantities of inorganic fertilizer applied differ more importantly from one farmer to another and range from $4.58 \%$ to $90.5 \%$ with a mean of $27.15 \%$ of the level recommended by research. However, nitrogen, phosphorous, potassium, organic carbon, $\mathrm{pH}$ water, and exchanging capacity cation determine the rainfed rice yield. The policies that aim at promoting inorganic fertilizer among rainfed rice farmers must take into account these factors.
\end{abstract}




\section{Keywords}

Endogenous Cropping Systems, Double Hurdle Model, Regression Tree, Inorganic Fertilizer

\section{Introduction}

In Benin, agriculture sector accounts for $34 \%$ of the gross domestic product (GDP) and provides about $80 \%$ of foreign exchange earnings [1]. Small-scale farmers dominate the sector. They mainly cultivate food crops and cotton. Major food crops include cereals, legume, root and tuber. As in Sub Sahara Africa countries, farmers record extremely low yield and the decline in soil fertility is the leading cause of the declining per capita food production [2]. In many cases, farmers' yields for cereals rarely exceed $0.5 \mathrm{t} \cdot \mathrm{ha}^{-1}$ while a potential of $6-8 \mathrm{t} \cdot \mathrm{ha}^{-1}$ is attained in research station trials and on commercial farms [3]. In fact, severe soil degradation can lead to such strong constraints that even legumes perform poorly and are unable to produce sufficient biomass [2]. Sustainable production requires that at least the nutrients removed through exportation of agricultural products be returned to the soil. Unfortunately, nutrient imbalance in agricultural production is currently one of the main threats to soil in Benin [4] [5] [6]. Then, inorganic fertilizer use is crucial for raising and sustaining farm productivity in Benin. However, Benin exhibits a low rate of fertilizer use with an average consumption estimated at less than $5 \mathrm{~kg} \cdot \mathrm{ha}^{-1}[7]$.

Among the major cereals, rice has become a priority commodity for food security in Benin. Rice consumption is growing faster than that of any other major staple on the continent because of high population growth, rapid urbanization and changes in eating habits [8]. This consumption is expected to continue to grow in the foreseeable future. Each person in the world consumes around $65 \mathrm{~kg}$ of rice a year, but in Africa this average varied between 16 and $32 \mathrm{~kg}$ of rice a year and could even reach $45.7 \mathrm{~kg}$ per habitant per year in Benin [9]. However, the local rice production doesn't cover the rice needs of the population. In West Africa most rice is grown under rainfed conditions and among the factors which limit the rice yield, plant nutrients are the major constraint in increasing of their production [10]. This is because of the severe nutrient depletion and the widespread decline in the fertility of African soils, leading to abysmally low rainfed rice yields. Fertilizers sustainably increase crop productivity to $50 \%-100 \%$ [2]. However, most part of the farmers hardly use external inputs and they are, therefore, strongly dependent on inherent soil fertility [11].

Over the years, soils in Benin are coming under increased pressure because of high population growth, increasing scarcity of arable land, and inappropriate land use [12]. This situation leads to greater intensity of soil use and loss of soil fertility. Evaluation of nutrient inputs, flows, and losses in Benin in 2000 concluded that nutrient losses from smallholder operations were $-16 \mathrm{~kg} \mathrm{~N},-2 \mathrm{~kg}$, 
and $-11 \mathrm{~kg} \mathrm{~K} \mathrm{ha}^{-1} \cdot \mathrm{year}^{-1}$ [2]. These negative nutrient balances of cropping system are increasing over the years. Cash crops like cotton tend to be much less depleting than food and fodder crops because they receive more fertilizer and manure. In order to promote increased staple production, the provision of subsidized fertilizer to farmers had been a major policy option, which was adopted in Benin [12]. However, knowledge about standard inorganic fertilizers formulation used by farmers in rainfed rice cultivation in Benin is scanty. Therefore, there is need to analyze the factors that influence inorganic fertilizer adoption and intensity use in Benin to establish a background information for developing better alternative to limit mineral deficiency in rice cultivation. This requires a deep understanding of the yield determinant as well as the endogenous practices used by farmers to maintain the soil fertility under rice cultivation in Benin.

\section{Material and Method}

\subsection{Study Areas}

This study was carried out in 11 municipalities in four agriculture development centers (ADC) of Benin (Figure 1). The municipalities of Banikoara and Kandi in cotton crop zone (Northern Benin; ADC 2); Ouèssè, Glazoué, Dassa-Zoumè and Djidja in cashew, cotton and food crops zone (Center Benin; ADC 4); Agbangnizoun, Zogbodomè, Kloukanmè and Djakotomè in Fruit trees and food crops zone (South Benin; ADC 5) and Kétou in palm oil and food crops zone (South Benin; ADC 6). In cotton crop zone, cotton is the main crop growth. The food crops like maize, sorghum, rice, and cowpea are grown to profit of carry-over effect of fertilizer. Intensive cattle farming is also practice. This zone of Benin (Department of Alibori) is between $10^{\circ} 31^{\prime} 19^{\prime \prime}$ and $11^{\circ} 45^{\prime} 00^{\prime \prime}$ of latitude north and between $2^{\circ} 3^{\prime} 00^{\prime \prime}$ and $3^{\circ} 16^{\prime} 30^{\prime \prime}$ of East longitude [13]. Its climate is North-Sudanian [14], whose seasonal rhythm is influenced by the displacement of the intertropical front. Average annual rainfall is around $850 \mathrm{~mm}$ [13]. Soils are Tropical Ferruginous leached with concretions on sand-clay sediments. A wide variety of crops is fund in cashew, cotton and food crops zone. Cotton and cashew are main crops of this zone. However, maize, rice, cassava, cowpea are also mostly grown and intensive cattle farming. This zone has a subequatorial climate influenced by the southern Sudanian area. The average annual rainfall is around $1100 \mathrm{~mm}$. In this zone there are Tropical Ferruginous soils, and Vertisols [15] [16] [17]. South Benin (Palm oil and food crops, fruit trees and food crops and fishing and market gardening zones) where food crops are mainly grown is characterized by Sudano-Guinean or subequatorial climate [15] [16] [17]. There are very rich loam-clay soils (valleys) and Ferrallitic soils. The annual rainfall generally recorded in the area varies between $800 \mathrm{~mm}$ to $1400 \mathrm{~mm}$. These municipalities were chosen on the basis of rice cultivation by farmers and they also belong to research and development sites of National Institute for Agriculture Research in Benin. 


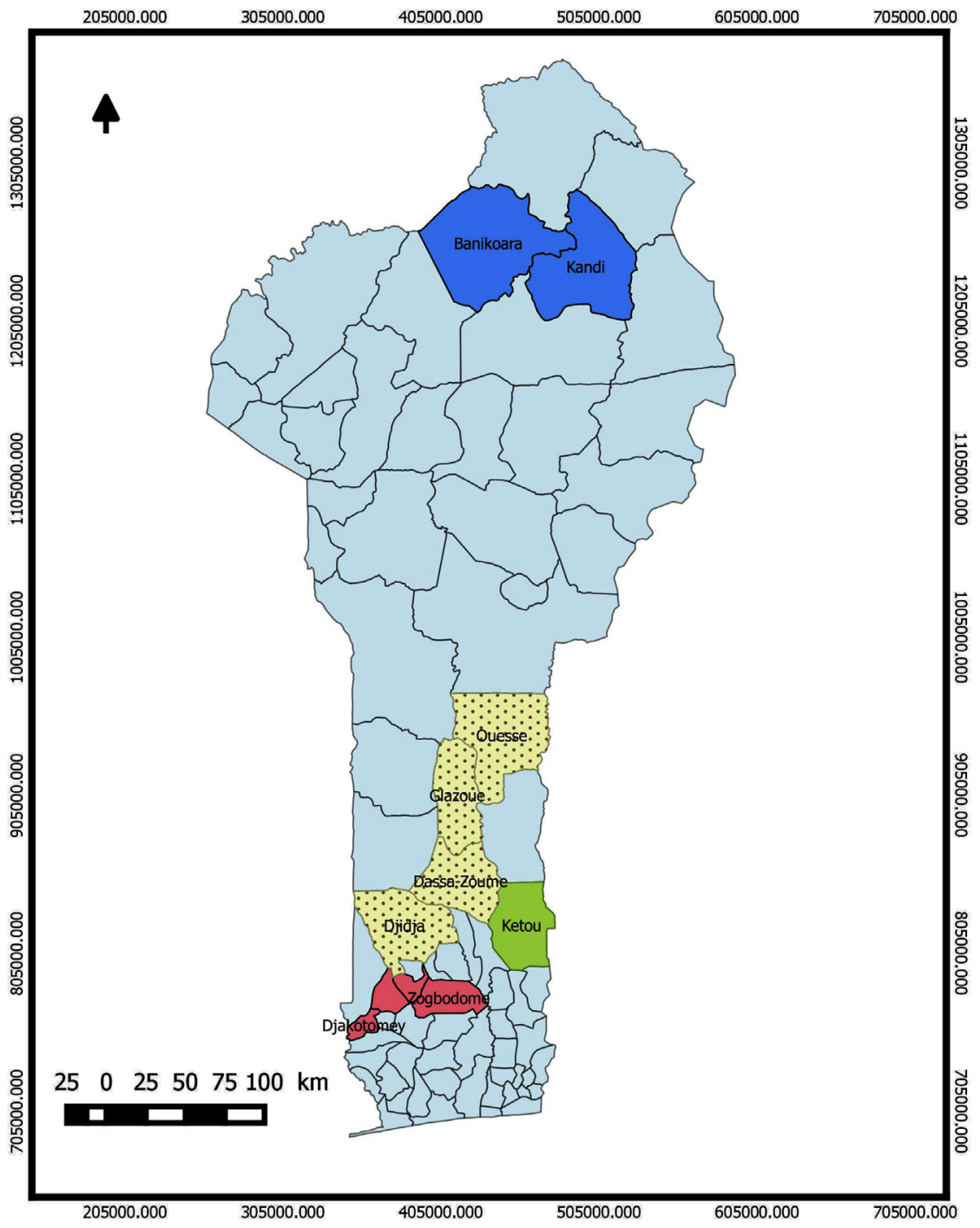

Study areas

Municipalities of ADC 2:Cotton crop zone

$\therefore \therefore$ Municipalities of ADC 4: Cashew, cotton and food crops zone

Municipalities of ADC 5: Fruit trees and food crops zone

Municipality of ADC 6: Palm oil and food crops zone

Benin

Figure 1. Map of Benin and study areas.

\subsection{Sampling Method and Data Collection}

The number of respondents was determined using the normal approximation of the binomial distribution proposed by Dagnelie [18] below:

$N_{i}=\left[\left(U_{1-\alpha / 2}\right)^{2} \times p_{i}\left(1-p_{i}\right)\right] / d^{2}$; where $N_{i}$ is the number of farmers investigated who grow rainfed rice, $U_{1-a / 2}$ is the value of the normal random variable for a probability of $1-\alpha / 2, \alpha$ the type I error. For $\alpha=5 \%$, the probability $1-\alpha / 2=$ 0.975 and we have $U_{1-\alpha / 2}=1.96 ; p_{i}$ is the proportion of people engaged in rainfed rice cultivation in the study areas and $d$ the estimation margin error, which is $5 \%$ for this study. $A_{i}$, the percentage of farmers engaged in rainfed rice grow in a 
municipality, $A_{i}=A c_{i} / A t_{i}\left(A c_{i}\right.$, the number of farmer of a municipality engaged in rainfed rice and $A t_{i}$ the total number of farmer of all the municipalities). The sample size of each municipality would be: $n=A_{i} * N_{i}$. In each municipality, farmers were identified using simple random sampling. Thus, in total, 763 rainfed rice farmers were surveyed from June to December 2017 (Table 1).

Data collected include socio-economic characteristics of farmers, agricultural practices of rainfed rice farmers. Composite soil samples were taken from 277rainfed rice fields of farmers and were analyzed at laboratory of Soil Science, Water and Environment in National Institute of Agricultural Research of Benin (NIARB) for the determination of physicochemical parameters. Rice paddy yield were collected where composite samples were taken.

\subsection{Soil Sampling Method}

Composite soil samples were collected at a depth of $0-20 \mathrm{~cm}$ in the different rainfed rice fields. The elementary samples were collected randomly in each rainfed rice field. At least, 16 elementary samples were collected per field as recommended by Schvartz et al. [19]. These elementary samples were collected to form a composite sample per field. In total, 277 composite soil samples were collected from 25, 26, 28, 27, 29, 23, 24, 25, 22, 25, 23 farmer's fields in Banikoara, Kandi, Ouèssè, Glazoué, Dassa-Zoumè, Djidja, Agbangnizoun, Zogbodomè, Kloukanmè, Djakotomè and Kétou respectively. The soil $\mathrm{pH}\left(\mathrm{H}_{2} \mathrm{O}, 1: 1\right)$, organic carbon, and total soil nitrogen contents, available Bray-1 phosphorous, exchangeable potassium and exchangeable capacity cation were analyzed according to the methods described by Dagbenonbakin [20].

\subsection{Data Processing and Analysis}

\subsubsection{Factors Influencing Inorganic Fertilizers Adoption and Use Intensity}

To analyze the mechanisms of inorganic fertilizers adoption and use intensity, the double hurdle model was used. In fact, surveys of smallholder inorganic fertilizers used are often characterized by a high proportion of zero use, and the choice of statistical technique to deal with zero use can be crucial for the empirical results produced. Inappropriate treatment of zero use can lead to biased and inconsistent estimates [21]. According to the same authors, the special feature of the double-hurdle approach is that it does not require the assumption that the determinants of inorganic fertilizers adoption (whether to adopt inorganic fertilizers) are the same as the determinants of inorganic fertilizers use intensity (how much to use).

First hurdle: According to this mechanism, the smallholder farmer's adoption decision of inorganic fertilizers is dichotomous. The smallholder farmer decides to include inorganic fertilizers in its cropping system or considers them harmful. It allowed accounting for the non-adoption of inorganic fertilizers as a consequence of several factors other than unrecognized and unavailable of inorganic 
Table 1. Socio-economic characteristics of rainfed rice farmers surveyed.

\begin{tabular}{cccccc}
\hline Variables & Modality & ADC 2 & ADC 4 & ADC 5 & ADC 6 \\
\hline Farmer surveyed & & 172 & 330 & 220 & 41 \\
Gender (\%) & Men & 77.2 & 85.7 & 78.1 & 88.3 \\
& Women & 22.8 & 14.3 & 21.9 & 11.7 \\
& Illiterate (0) & 81.2 & 69.4 & 61.3 & 45.4 \\
Educational level (\%) & Primary School (1) & 11.5 & 28.6 & 28.2 & 35.4 \\
& Secondary School (2) & 7.3 & 2 & 10.5 & 19.2 \\
& <30 years & 35.4 & 33.5 & 25.8 & 23.1 \\
Age (\%) & Between 30 and 60 years & 48.9 & 51.9 & 61.5 & 74.2 \\
& $>60$ years & 15.7 & 14.6 & 12.7 & 2.7 \\
\hline
\end{tabular}

ADC: Agriculture Development Centers.

fertilizers. Then, the inorganic fertilizer adoption mechanism is a binary choice that can be coded by a binary variable $I_{1}$ taking value 1 if the smallholder farmer decides to use inorganic fertilizer and 0 otherwise. The outcome of this binary choices is modeled by associating the decision to adopt inorganic fertilizer to positive values of the latent variable $y_{1}^{*}$ and that to reject inorganic fertilizer to negative values of $y_{1}^{*}$. Therefore, inorganic fertilizer adoption or rejection is modeled as a probability choice where adoption occurs with probability $P\left(I_{1}=1\right)=P\left(y_{1}^{*}>0\right)$ and rejection with probability $P\left(I_{1}=0\right)=P\left(y_{1}^{*} \leq 0\right)=1-P\left(y_{1}^{*}>0\right)$. As the dependent variable is dichotomous, the probity regression model was used to quantify the factors influencing the probability of inorganic fertilizer technology adoption among rainfed rice farmers in Benin.

$$
y_{1}^{*}=\beta_{1} \varkappa_{1}+\epsilon_{1}
$$

where $\varkappa_{1}$ are the explanatory variables (age of farmer, gender, marital status, educational status, household size, nativity of farmer, membership of farmer, access to credit, training of farmer on soil fertility, filed areas sown with rice, contribution of rice to household income, years of farming experience, inorganic fertilizers availability and organic fertilizer use), $\beta_{1}$ the impact coefficients of the explanatory variables on the continuous latent dependent variables $y_{1}^{*}$ and $\epsilon_{1}$ for normal random disturbances.

Second hurdle: The second level of this analysis involved the determination of the factors that influences inorganic fertilizer use intensity. Once inorganic fertilizer technology has been adopted, the rainfed rice farmer decides which amount to supply. The intensity of inorganic fertilizer use $(y)$ is specified as:

$$
y=\frac{\text { Quantity of inorganic fertilizer use }(\mathrm{kg})}{\text { Total area of land under rainfed rice crop }(\mathrm{ha})}
$$

This second hurdle uses the truncated regression model to determine the extent of inorganic fertilizer use intensity. 


$$
y_{2}^{*}=\beta_{2} \varkappa_{2}+\epsilon_{2}
$$

where $\varkappa_{2}$ are the explanatory variables (age of farmer, gender, marital status, educational status, household size, nativity of farmer, membership of farmer, access to credit, training of farmer on soil fertility, field areas sown with rice, contribution of rice to household income, years of farming experience, inorganic fertilizers availability and organic fertilizer use), $\beta_{2}$ the impact coefficients of the explanatory variables on the continuous latent dependent variables $y_{2}^{*}$ and $\epsilon_{2}$ for normal random disturbances.

$$
y=\left\{\begin{array}{lc}
y_{2}^{*} & \text { if } y_{2}^{*}>0 \text { and } I_{1}=1 \\
0 & \text { otherwise }
\end{array}\right.
$$

where $y$ is the inorganic fertilizer use intensity which depends on the latent variable $y_{2}^{*}$ being greater than zero and conditional to the decision to adopt inorganic fertilizer $\left(I_{1}\right)$.

\subsubsection{Statistical Analysis}

Quantitative data from the individual survey were submitted to fixe effect linear model using the $\mathrm{Im}$ function of $\mathrm{R}$ software version 3.5.1. Multiple mean comparisons were performed using the Student Newman-Keuls test [22] with SNK test function of the Agricolae package in R [23]. The packages FactoMineR [24] and Factoextra [25] with the functions $M C A, H C P C$ and fviz_dend were used to run multiple correspondence analysis followed by a hierarchical clustering of the survey data related to cropping systems. This allowed identifying the dominant cropping systems and the distribution of farmers according to the systems. Correspondence analysis was performed using the $C A$ function of FactoMineR package [24] to visualize the association between rainfed rice cropping systems and municipalities. The packages mhurdle [26] was used to perform the double-hurdle model. The packages rpart [27] and partykit [28] were used to carry out the regression tree that identifies the determinants of rainfed rice yield.

\section{Results and Discussion}

\subsection{Endogenous Rainfed Rice Cropping System}

Four cropping systems (cluster) emerged from multiple correspondence analyses and ascending hierarchical classification results (Figure 2). Tillage method, crop residues use, rice varieties, crops rotation, seeds origin, organic fertilizers use and seeding mode are variables strongly link to cropping system $(\mathrm{p}<0.0001)$. First cluster (system 1) includes farmers who practiced manual tillage, used organic fertilizer, left crop residues in fields and practiced direct seeding of local variety obtained from last harvest. Second cluster (system 2) includes farmers who practiced mechanical tillage; nursery of improved varieties obtained from research center, used only inorganic fertilizer, left crop residues in fields and practiced crop rotation. Third cluster (system 3) represents farmers who practiced manual tillage; direct seeding of improved varieties obtained from research 
Cluster Dendrogram

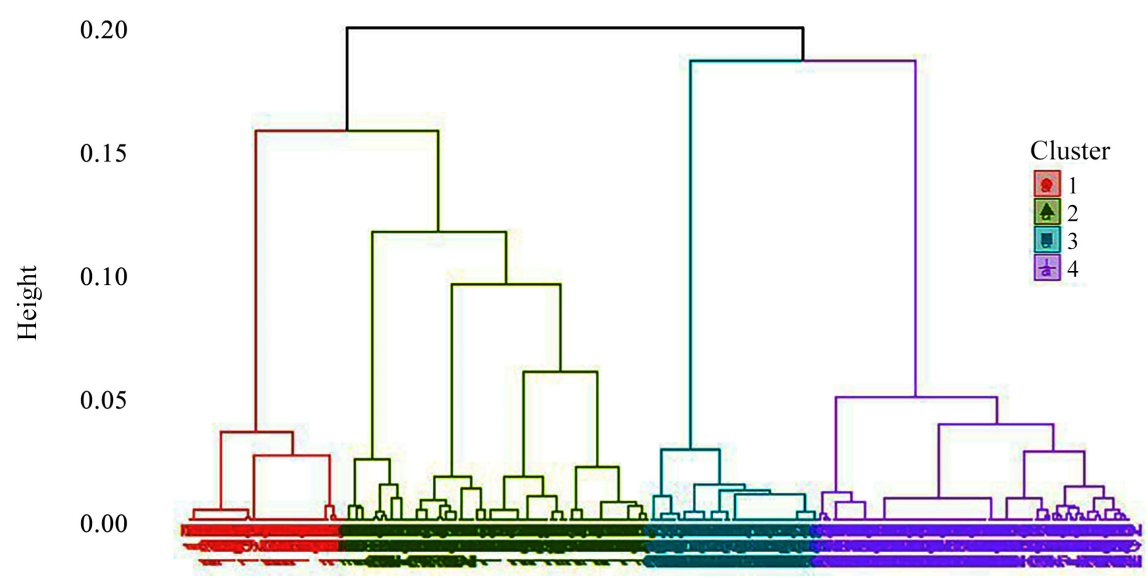

Figure 2. Dendrogram relating to the ascending hierarchical classification.

center, did not use fertilizer and burnt crop residues. Fourth cluster (system 4) represents farmers who practiced harness tillage; direct seeding of local variety obtained from local markets or last harvest, did not use fertilizer and used crop residues as animal feed. However, $34.82 \% 19.1 \%, 23.04 \%$ and $23.04 \%$ of farmers adopted system 1, system 2, system 3 and system 4 respectively. These cropping system influenced rainfed rice yield. In fact, plant residues management and ploughing method determine rice yield [29]. The positive effect of rice crop residues incorporation into soils on rice yields has been reported previously by Zingore et al. [30]. Machine tillage improved permeability; percolation as well as water retention capacity that increase rice yield [29]. Farmers of Center Benin mostly adopted the system 1 and system 3 , while those of southern and northern Benin adopted the system 2 and system 4 respectively (Figure 3 ). The area used for rainfed rice by farmers who practiced the system 3 is higher than that used by farmers for other systems (Table 2). Inorganic fertilizer use is not variable link to rainfed rice cropping system. Then, inorganic fertilizer's adoption was not determined by rice cropping systems.

\subsection{Determinants of Inorganic Fertilizers Adoption and Use Intensity}

Inorganic fertilizer use intensity ranged from 12.6 to $248.9 \mathrm{~kg} \cdot \mathrm{ha}^{-1}$ with a mean of $74.68 \mathrm{~kg} \cdot \mathrm{ha}^{-1}$. The results of double hurdle model of factors influencing adoption and use intensity of inorganic fertilizer by rainfed rice farmers (Table 3 ) showed many factors determine inorganic fertilizer adoption (hurdle 1) and use intensity (hurdle 2). Inorganic fertilizer technology adoption depends significantly of age, educational status, Household size, contribution of rice to household income and organic fertilizer use. However, use intensity of inorganic fertilizer is significantly influenced by the age of farmer, training of farmer on soil fertility, filed areas under rice crop, contribution of rice to household income, years of farming experience, inorganic fertilizers availability and organic fertilizer 
Table 2. Socio-economic characteristics of rainfed rice farmers according to cropping systems.

\begin{tabular}{ccccccc}
\hline System & Ages (years) & $\begin{array}{c}\text { Household } \\
\text { size (person) }\end{array}$ & $\begin{array}{c}\text { Available area } \\
\text { for agriculture } \\
\text { (ha) }\end{array}$ & $\begin{array}{c}\text { Area } \\
\text { exploited for } \\
\text { agriculture } \\
\text { (ha) }\end{array}$ & $\begin{array}{c}\text { Rice } \\
\text { area (ha) }\end{array}$ & $\begin{array}{c}\text { Experience } \\
\text { in rice } \\
\text { production } \\
\text { (years) }\end{array}$ \\
\hline System_1 & $41.09 \pm 9.11 \mathrm{a}$ & $7.66 \pm 3.86$ & $14.4 \pm 5.77 \mathrm{a}$ & $11.24 \pm 4.07 \mathrm{a}$ & $0.73 \pm 0.65 \mathrm{c}$ & $9.85 \pm 5.56 \mathrm{~b}$ \\
System_2 & $39.43 \pm 6.74 \mathrm{a}$ & $8.46 \pm 3.44 \mathrm{a}$ & $6.54 \pm 5.98 \mathrm{c}$ & $4.83 \pm 1.66 \mathrm{~b}$ & $1.46 \pm 0.6 \mathrm{~b}$ & $11.86 \pm 6.98 \mathrm{a}$ \\
System_3 & $39.28 \pm 8.47 \mathrm{a}$ & $7.28 \pm 2.11 \mathrm{a}$ & $11.92 \pm 6.48 \mathrm{~b}$ & $10.16 \pm 3.91 \mathrm{a}$ & $2.22 \pm 0.82 \mathrm{a}$ & $8.17 \pm 5.12 \mathrm{~b}$ \\
System_4 & $38.26 \pm 10.21 \mathrm{a}$ & $7.43 \pm 3.81 \mathrm{a}$ & $9.86 \pm 6.40 \mathrm{bc}$ & $8.5 \pm 3.35 \mathrm{a}$ & $0.78 \pm 0.63 \mathrm{c}$ & $9.94 \pm 6.56 \mathrm{~b}$ \\
p-value & 0.265 & 0.176 & $\mathrm{P}<0.0001$ & $\mathrm{P}<0.0001$ & $\mathrm{P}<0.0001$ & 0.0019 \\
\hline
\end{tabular}

Means followed by the same alphabetical letters and for the same variables are not significantly different ( $p>0.05$ ) according to the Student Newman-Keuls test.

Table 3. Double hurdle estimates of inorganic fertilizer adoption and use intensity.

\begin{tabular}{|c|c|c|c|c|}
\hline \multirow{2}{*}{ Independent variable } & \multicolumn{2}{|c|}{$\begin{array}{l}\text { Inorganic fertilizer } \\
\text { adoption (Hurdle 1) }\end{array}$} & \multicolumn{2}{|c|}{$\begin{array}{c}\text { Inorganic fertilizer use } \\
\text { intensity (Hurdle 2) }\end{array}$} \\
\hline & $\begin{array}{l}\text { Parameter } \\
\text { estimate }\end{array}$ & $\begin{array}{l}\text { Standard } \\
\text { error }\end{array}$ & $\begin{array}{l}\text { Parameter } \\
\text { estimate }\end{array}$ & $\begin{array}{c}\text { Standard } \\
\text { error }\end{array}$ \\
\hline Intercept & $5.45^{* *}$ & 2.41 & $7.53^{\star * *}$ & 0.27 \\
\hline Gender of farmer-Male & 1.39 & 0.11 & 0.13 & 0.07 \\
\hline Age of farmer & $-2.39^{* *}$ & 0.01 & $1.48^{* *}$ & 0.03 \\
\hline Marital status of farmer-single & 1.56 & 0.45 & 0.56 & 0.29 \\
\hline Educational status of farmer & $0.89^{* *}$ & 0.39 & -0.04 & 0.08 \\
\hline Household size of farmer & $1.79^{*}$ & 0.47 & 0.11 & 0.09 \\
\hline Nativity of farmer-migrant & -10.93 & 2.31 & 0.06 & 0.16 \\
\hline Membership of farmer organization-Yes & -0.16 & 0.34 & 0.03 & 0.08 \\
\hline Training of farmer on soil fertility-Yes & 0.14 & 0.33 & $0.38^{\star * *}$ & 0.09 \\
\hline Filed areas sown with rice & 0.12 & 0.12 & $-0.13^{*}$ & 0.03 \\
\hline Contribution of rice to household income & $8.57^{*}$ & 0.43 & $0.14^{* *}$ & 0.07 \\
\hline Years of farming experience & 0.36 & 0.18 & $0.39^{* *}$ & 0.02 \\
\hline Access to credit-Yes & 0.24 & 0.23 & 0.01 & 0.06 \\
\hline Inorganic fertilizers availability & 0.32 & 0.41 & $1.24^{\star *}$ & 0.85 \\
\hline Organic fertilizer use-Yes & $0.93^{*}$ & 0.42 & $-0.27^{\star \star}$ & 0.09 \\
\hline sd.sd & - & - & $0.49^{* * *}$ & 0.02 \\
\hline Frequency of 0 & \multicolumn{4}{|c|}{0.23} \\
\hline Log-Likelihood & \multicolumn{4}{|c|}{-318.98 on $52 \mathrm{Df}$} \\
\hline Pseudo R-Squared & \multicolumn{4}{|c|}{0.3743} \\
\hline Likelihood ratio index & \multicolumn{4}{|c|}{0.23972} \\
\hline
\end{tabular}

Note: ${ }^{*}{ }^{* *},{ }^{* *}$ indicates that the corresponding coefficients are significant at the $5 \%, 1 \%$, and $1 \%$ o levels respectively. 


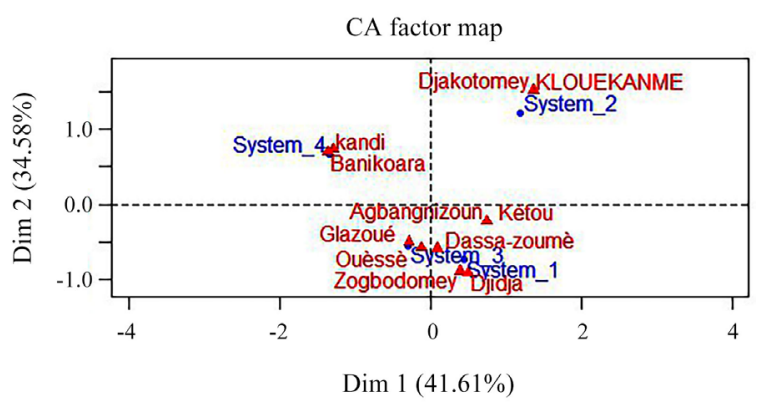

Figure 3. Representation of systems and towns in the plan (Axis 1, Axis 2).

use. The age of farmers was significant $(\mathrm{p}=0.004)$ and influenced negatively inorganic fertilizer technology adoption. The result implied that older rainfed rice farmers were less likely to adopt inorganic fertilizer. This result was similar with those found by [31]. However, the age of farmers was also significant $(p=0.006)$ and positively affected by inorganic fertilizer intensity use. In fact, older farmers were more risk averse and were assessed the attributes of a technology than younger farmers [31]. However, they were more financially able to intensify inorganic fertilizer use than young farmers. Educational status of farmers was significant $(\mathrm{p}=0.008)$ and was positively related to adoption, suggesting that the more educated farmers were more likely to adopt inorganic fertilizer than, the less illiterate farmers. This result corroborated with those observed by Chianu and Tsujii [32] showing that the level of education of the household head affected positively and significantly the farmers' decision to adopt or not inorganic fertilizer in the savannas of northern Nigeria.

Inorganic fertilizer adoption was significantly $(\mathrm{p}=0.034)$ influenced by farmer household size. This result implied that farmers with high household size adopt more inorganic fertilizer than farmers with less household size. Indeed, inorganic fertilizer technology adoption requires more workers that can be provided by memberships of the farmer household. Training of farmer on soil fertility is also significant $(\mathrm{p}<0.0001)$ and positively liked with inorganic fertilizer use intensity. The farmers who participated to soil fertility management training at least one time ago use more fertilizer $\left(96.45 \pm 25.8 \mathrm{~kg} \cdot \mathrm{ha}^{-1}\right)$ than those who never participated $\left(35.12 \pm 11.56 \mathrm{~kg} \cdot \mathrm{ha}^{-1}\right)$. However, inorganic fertilizer use intensity was negatively related to the area under rainfed rice crop $(p=0.023)$. The implication of the result was that, as farm size increases, farmers were more likely to use less inorganic fertilizer amount per hectare. The result confirmed those found by Edward et al. [31] about the negative relation between area under cultivation and inorganic fertilizer adoption. Contribution of rice to household income is significant $(p=0.015)$ and positively linked to inorganic fertilizer adoption. It's also significantly $(\mathrm{p}=0.003)$ linked to the use intensity of inorganic fertilizer. In fact, farmers who earned a substantial income from rice cultivation are predisposed to adopt new technologies to increase their production. They also made more effort to comply with good fertility management practices 
and a higher use of inorganic fertilizers. Inorganic fertilizer use intensity was significantly $(p=0.007)$ related to years of farming experience. Farmers, who have been growing rainfed rice for a long time, use more inorganic fertilizer than those who started to grow rainfed rice. This result implied that farmers with experience in inorganic fertilizer technology easily intensify the amount used especially with the decline of soil fertility. Those farmers perceived more the negative effect of declining soil fertility so they use more inorganic fertilizer.

Inorganic fertilizers availability was significant $(\mathrm{p}=0.006)$ and positively related to its use intensity. Farmers used more inorganic fertilizer when the latter is available and accessible to them. Likewise, organic fertilizer use was positively $(\mathrm{p}=0.034)$ linked to inorganic fertilizer adoption and negatively $(\mathrm{p}=0.005)$ linked to its use intensity. This result suggested that higher quantity of organic manure applied, reduced the amount of inorganic fertilizer used. This was probably because farmers understand the complementary relationship derivable from the combined application of organic manure and inorganic fertilizer. This corroborates the finding of Chianu and Tsujii [32]. These different results showed that inorganic fertilizer technology was not a variable determining the soil fertility management by rainfed rice farmers. However, low yields were recorded in rice cropping systems. Policies to promote the adoption of inorganic fertilizers should target young rice farmers with at least primary school education level in order to hope that this technology will be adopted. Local rice markets need to be stimulated to increase local production of rice. This would lead farmers to increase plantings areas which was a determining factor in the adoption and intense use of inorganic fertilizer. The development of local rice markets would increase farmers' incomes, which was also determinant in the adoption and use intensity of inorganic fertilizers.

\subsection{Determinants of Rainfed Rice Yield}

The regression tree (Figure 4) showed that nitrogen, phosphorous, potassium, organic carbon, $\mathrm{pH}$ water, and exchanging capacity cation determined the rainfed rice yield in traditional cropping system. Nitrogen was the root of the tree so it was the main soil parameter that determines rainfed rice yield. Lower content of nitrogen $(<0.054 \%)$ induces lower rice yield even others nutrient. This result was in accordance with the finding of Atsuko et al. [29] who showed that nitrogen application rate strongly determines the rice yield in southern-central Benin. Nitrogen is the most important variable that limits rice yield [33]. The phosphorous impact on rice yield was also reported by Dakshina-Murthy et al. [34] who observed increasing of rice yield with phosphorous supplying. Phosphorous application induced increasing of rice yield and quality [10]. Then, rice cultivation in Benin need to supply phosphorous because in tropical Africa soil, phosphorous availability of plant was the lowest due to susceptibility losses by leaching, run off (on sandy textured soils) and fixation by soil inorganic colloids [35]. Potassium influence on rice yield was reported by 


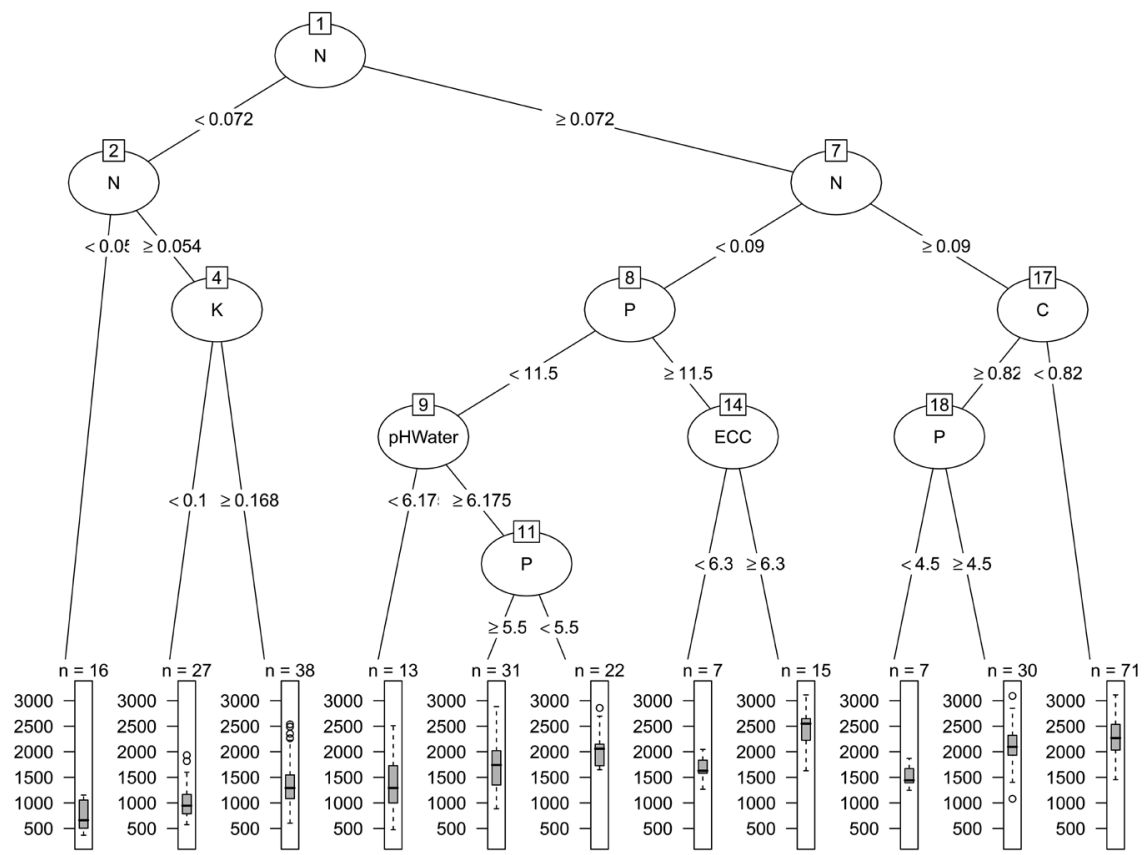

Figure 4. Regression tree of determinant of rainfed rice yield.

many authors [36] [37]. Soil acidity induces high amounts of exchangeable aluminum (Al) that was a severe constraint to crop productivity because it reduces the availability of many nutrients (e.g. $\mathrm{P}, \mathrm{Ca}, \mathrm{Mg}, \mathrm{Zn}$ ) and inhibits root growth of most plants and limits nutrient to uptake [38]. The implication of the result of regression tree (Figure 4) was to increase rice yield, farmers need to use inorganic fertilizer in adequate amount. However, many of them did not adopt inorganic fertilizer technology (23\%) and among farmers who adopted this technology, they used less than recommended rate of inorganic fertilizers (275 $\mathrm{kg} \cdot \mathrm{ha}^{-1}$ ) which are $200 \mathrm{~kg} \cdot \mathrm{ha}^{-1} \mathrm{~N}_{15} \mathrm{P}_{15} \mathrm{~K}_{15}$ and $75 \mathrm{~kg} \cdot \mathrm{ha}^{-1}$ of urea $46 \%$ [39]. This situation leads lower rice yield in traditional cropping systems.

\section{Conclusion}

The results from this paper indicated that inorganic fertilizer technology was not a variable significantly linked to endogenous rainfed rice cropping system. In the four rainfed cropping systems a low application rate among the farmers that use inorganic fertilizers was noticed. The application rate ranges from 12.6 to 248.9 $\mathrm{kg} \cdot \mathrm{ha}^{-1}$ with a mean of $74.68 \mathrm{~kg} \cdot \mathrm{ha}^{-1}$. The quantities of inorganic fertilizer applied differ more importantly from one farmer to another and range from $4.58 \%$ to $90.5 \%$ with a mean of $27.15 \%$ of the level recommended by research. Results from the double hurdle model have provided insight on pathways to increase the adoption of inorganic fertilizer. The targeting of young farmers who have at least primary school level when promoting inorganic fertilizer technology can increase the probability of adoption. Also urgent were policies to promote local rice cultivation and increase local rice commercialization. Regular trainings should be made to the farmers on soil fertility management to increase the 
amount of inorganic fertilizer use. Policies to make available inorganic fertilizer are also urgent to enhance its use intensity. This is also important since the rainfed rice yield is strongly determined by the nutrients such as nitrogen, phosphorous, potassium and others that are provided by fertilizer. Currently, it needs to assess the nutrient balance of rice crop in these endogenous cropping systems.

\section{Acknowledgements}

The authors are grateful to the Islamic Development Bank (IsBD) through Smallholder Agricultural Production Enhancement Program (SAPEP) for financial support and giving the opportunity to carry out this study.

\section{Conflicts of Interest}

The authors declare no conflicts of interest regarding the publication of this paper.

\section{References}

[1] ADB (African Development Bank) (2000) African Development Report 1999, Abidjan, Cote d'Ivoire. Oxford University Press, New York.

[2] Chianu, J., Chianu, J. and Mairura (2012) Mineral Fertilizers in the Farming Systems of Sub-Saharan Africa. A Review. Agronomy for Sustainable Development, 32, 545-566. https://doi.org/10.1007/s13593-011-0050-0

[3] Bationo, A., Waswa, B., Kihara, J. and Kimetu, J. (2006) Advances in Integrated Soil Fertility Management in Sub-Saharan Africa: Challenges and Opportunities. $\mathrm{Nu}$ trient Cycling in Agroecosystems, 76, 2-3. https://doi.org/10.1007/978-1-4020-5760-1

[4] Jones, A., Breuning-Madsen, H., Brossard, M., Dampha, A., Deckers, J., Dewitte, O., Gallali, T., et al. (2013) Soil Atlas of Africa. European Commission, Publications Ofce of the European Union, Luxembourg.

[5] Montanarella, L., Pennock, D.J., McKenzie, N., Badraoui, M., Chude, V., Baptista, I., et al. (2016) World's Soils Are under Threat. Soil, 2, 79-82. https://doi.org/10.5194/soil-2-79-2016

[6] William, J.B., Emmanuel, F., Stephen, K. and Thom, S.J. (2019) Understanding Fertilizer Adoption and Effectiveness on Maize in Zambia. Food Policy, 86, Article ID: 101721. https://doi.org/10.1016/j.foodpol.2019.05.004

[7] Druilhe, Z. and Barreiro-Hurlé, J. (2012) Fertilizer Subsidies in Sub-Saharan Africa. ESA Working Paper No. 12-04. FAO, Rome.

[8] Seck, P.A., Toure, A.A., Coulibaly, J.Y., Diagne, A. and Wopereis, M.C.S. (2013) Impact of Rice Research on Income, Poverty and Food Security in Africa: An Ex-Ante Analysis. In: Wopereis, M.C.S., Johnson, D.E., Ahmadi, N., Tollens, E. and Jalloh, A., Eds., Realizing Africa's Rice Promise, CAB International, Wallingford, UK, 24-33.

[9] Mohanty, S., Wassmann, R., Nelson, A., Moya, P. and Jagadish, S.V.K. (2013) Rice and Climate Change: Significance for Food Security and Vulnerability. IRRI Discussion Paper Series No. 49. International Rice Research Institute, Los Baños, Philippines, $14 \mathrm{p}$. 
[10] Badawi, M.A., Seadh, S.E., Naeem, E.S.B. and El-Iraqi, A.S.E.I. (2017) Effect of Phosphorus Fertilizer Levels on Productivity and Grains Quality of Some Rice Cultivars. Journal of Plant Production, 8, 411-415. https://doi.org/10.21608/jpp.2017.39996

[11] Haefele, S.M., Saito, K., N’Diaye, K.M., Mussgnug, F., Nelson, A. and Wopereis, M.C.S. (2013) Increasing Rice Productivity through Improved Nutrient Use in Africa. In: Wopereis, M.C.S., et al., Eds., Realizing Africa's Rice Promise, CAB International, Wallingford, UK.

[12] Kormawa, P., Munyemana, A. and Soule, B. (2003) Fertilizer Market Reforms and Factors Influencing Fertilizer Use by Small-Scale Farmers in Benin. Agriculture, Ecosystems and Environment, 100, 129-136. https://doi.org/10.1016/S0167-8809(03)00181-6

[13] Mama, A., Sinsin, B., De Canniere, C. and Bogaert, J. (2013) Anthropization and Landscape Dynamics in the Sudanian Zone in Northern Benin. Tropicultura, 31, 78-88. (In French)

[14] Hountondji, Y.-C.H. (2008) Environmental Dynamics in the Sahelian and Sudanian Zones of West Africa: Analysis of Changes and Evaluation of Vegetation Cover Degradation (In French). PhD Thesis, University of Liège, Liège.

[15] Dagbenonbakin, G. and Sokpon, N. (2003) Soil Capacities and Their Distribution in Benin: State of Play and Prospects for Development by 2025. Study No. 12. Final Report. Ministry of the Environment, Housing and Urban Planning, Directorate of Spatial Planning. (In French)

[16] Azontonde, H.M., Igue, M. and Dagbenonbakin, G. (2016) The Soil Fertility Map by Agro-Ecological Zone of Benin. Validated in 2016 Legal Deposit No. 9045. (In French)

[17] Kouélo, A.F., Badou, A., Houngnandan, P., Francisco, M.M.F., Gnimassoun, C.J.-B. and Sochime, D.J. (2012) Impact of Tillage and Mineral Fertilization on the Productivity of Macrotyloma geocarpum (Harms) in Central Benin (in French). Journal of Applied Biosciences, 51, 3625-3632.

[18] Dagnelie, P. (1998) Statistiques théoriques et appliquées. De Boeck, Brussels, 517 p.

[19] Schvartz, C., Decroux, J. and Muller, J.-C. (2005) Guide de la fertilisation raisonné. Editions France Agricole.

[20] Dagbenonbakin, G.D. (2005) Productivity and Water Use Efficiency of Important Crops in the Upper Oueme Catchment: Influence of Nutrient Limitations, Nutrient Balances and Soil Fertility. Ph.D. Thesis, University of Bonn, Bonn, Germany.

[21] Jones, A. and Yen, S (2000) A Box-Cox Double-Hurdle Model. Manchester School, 68, 203-221. https://doi.org/10.1111/1467-9957.00190

[22] Dagnelie, P. (1986) Theory and Statistical Methods. Agronomic Applications. Volume 2, Les presses agronomiques de Gembloux, A.S.B.L., Belgique, 463. (In French)

[23] De Mendiburu, F. (2014) Statistical Procedures for Agricultural Research. http://tarwi.lamolina.edu.pe/ fmendiburu

[24] Husson, F., Josse, J., Le, S. and Mazet, J. (2019) Multivariate Exploratory Data Analysis and Data Mining with R. http://factominer.free.fr

[25] Alboukadel, K. and Fabian, M. (2017) Extract and Visualize the Results of Multivariate Data Analyses. http://www.sthda.com/english/rpkgs/factoextra

[26] Yves, C., Fabrizio, C. and Stephane, H. (2018) Multiple Hurdle Tobit Models. https://www.R-project.org 
[27] Terry, T., Beth, A. and Brian, R. (2019) Recursive Partitioning and Regression Trees. https://github.com/bethatkinson/rpart

[28] Torsten, H., Heidi, S. and Achim, Z. (2019) A Toolkit for Recursive Partitioning. http://partykit.R-Forge.R-project.org/partykit

[29] Atsuko, T., Kazuki, S., Komla, A. and Kazuhiko, K. (2013) Factors Affecting Variation in Farm Yields of Irrigated Lowland Rice in Southern-Central Benin. European Journal of Agronomy, 44, 46-53. https://doi.org/10.1016/j.eja.2012.08.002

[30] Zingore, S., Wairegi, L. and Ndiaye, M.K. (2014) Guide for the Management of Rice Farming Systems. African Consortium for Soil Health, Nairobi (In French).

[31] Edward, M., Alexander, N.W., Prince, M.E., Mathias, F., Buah, S.S.J., John, B., Benjamin, D.K.A. and Francis, K. (2014) Fertilizer Adoption and Use Intensity among Smallholder Farmers in Northern Ghana: A Case Study of the AGRA Soil Health Project. Sustainable Agriculture Research, 3.

[32] Chianu, J.N. and Tsujii, H. (2004) Determinant of Farmer's Decision to Adopt or not to Adopt Inorganic Fertilizer in Savanna of Northern Nigeria. Nutrient Cycling in Agroecosystems, 70, 293-301. https://doi.org/10.1007/s10705-004-0715-Z

[33] Wang, Y.Y., Zhu, B., Shi, Y. and Hu, C.S. (2008) Effect of Nitrogen Fertilization on Upland Rice Based on Pot Experiments. Communications in Soil Science and Plant Analysis, 39, 1733-1749. https://doi.org/10.1080/00103620802073743

[34] Dakshina-Murthy, K.M., Upendra-Rao, A., Vijay, D. and Sridhar, T.V. (2015) Effect of Levels of Nitrogen, Phosphorus and Potassium on Performance of Rice. Journal of Plant Nutrition, 49, 83-87. https://doi.org/10.5958/0976-058X.2015.00012.8

[35] Fageria, N.K., Baligar, V.C. and Li, Y.C. (2008) The Role of Nutrient Efficient Plants in Improving Crop Yields in the Twenty First Century. Journal of Plant Nutrition, 31, 1121-1157. https://doi.org/10.1080/01904160802116068

[36] Sahar, M. and Tayeb, S.N. (2014) The Effect of Different Levels of Humic Acid and Potassium Fertilizer on Physiological Indices of Growth. International Journal of Biosciences, 5, 99-105. http://www.innspub.net https://doi.org/10.12692/ijb/5.2.99-105

[37] Nurul, A.M.Z. and Mohd, R.I. (2016) Effects of Potassium Rates and Types on Growth, Leaf Gas Exchange and Biochemical Changes in Rice (Oryza sativa) Planted under Cyclic Water Stress. Agricultural Water Management, 164, 83-90. https://doi.org/10.1016/j.agwat.2015.09.022

[38] Vanlauwe, B., Descheemaeker, K., Giller, K.E., Huising, J., Merckx, R., Nziguheba, G., Wendt, J. and Zingore, S. (2015) Integrated Soil Fertility Management in Sub-Saharan Africa: Unravelling Local Adaptation. Soil, 1, 491-508. https://doi.org/10.5194/soil-1-491-2015

[39] Yabi, R.W. (2013) Production Techniques of IR 841 Rice in the Lowlands of Glazoué-Hills Department (Center Benin). Regional Fund for Agricultural Extension (FoReVA). (In French) 